\title{
The Nietzsche's Reflection on History: Historical Sense and Nihilism
}

\author{
José Ncolao Julião \\ Departament of Universidade Federal Rural do Rio de Janeiro, Rio de Janeiro, Brazil \\ Email: jnjnicolao@gmail.com
}

How to cite this paper: Julião, J. N. (2018). The Nietzsche's Reflection on History: Historical Sense and Nihilism. Open Journal of Philosophy, 8, 77-84. https://doi.org/10.4236/ojpp.2018.82007

Received: November 7, 2017

Accepted: March 4, 2018

Published: March 7, 2018

Copyright (C) 2018 by author and Scientific Research Publishing Inc. This work is licensed under the Creative Commons Attribution International License (CC BY 4.0).

http://creativecommons.org/licenses/by/4.0/

\begin{abstract}
The present article aims to investigate the narratives considerations of Nietzsche's history, based on his writings in which the critique of historical culture is revealed from its lack of historical sense and his nihilist state, establishing a close relationship between the two themes, making the understanding of the second magnify its critical position.
\end{abstract}

\section{Keywords}

Historical Sense, Nihilism, History

\section{Introduction}

The objective of this research is to investigate the Nietzsche's reflection concerning history, having as base his writings, in which the critical one of culture is disclosed from his lack of historical sense (historische Sinn) and his nihilist state. The occult subject of these writings is the historicity of the man, which means, the verification of a state of degeneration of the humanity, disclosed in his historical process. For the considered one: 1) at a first moment, we will try to show as the referring texts to the subject of the historical sense are significant, for indicating the danger that the history excess results for the culture, and for the interpretation of the existence human being at the light of the structure of the time in the past dimensions, present and future, that, instead of giving a sense to it, finishes disclosing lacks of this. 2) At a second moment, we intend to approach as Nietzsche, under the nihilism concept, from 1881, establishes an extended notion of history, that can be understood as being a crisis not only of the distinctive lack of historical sense, but also of the most basic values with which lead human being history as a whole.

Our interpretative provisory hypothesis is that, from the sprouting of the ni- 
hilism concept, in his work, Nietzsche extends his reflection on the history of humanity, understanding it as being a process of disease development and decline, such as already appeared, initially, in The Use and Abuse of History (1874) end, later, in 1881, in aphorism 337 of The Gay Science (GS), but even so now with the problematic one of the nihilism, also appears a reflection on the possibility of the overcoming this "pathological" state, from a "revaluation of all values" (Umwerthung to aller Werthe) that they conduct the culture.

\section{Historical Sense}

The philosophical attitude of Nietzsche, critical of the occidental historical culture, fits perfectly in the panoramic picture of the intellectual quarrels of Germany from his epoch: side for, marked by the optimistically interpretations of the Enlightenment (Aufklärung), represented by the followers of the German idealism and by the positivism-scientific as philosophical-that they have a teleological, evolutionary and performative conception of the process of the development of the culture, directed by the reason; on the other side, marked by the Schopenhauer's philosophy, whose critical to the progress, the optimism and the idealism of the absolute reason, added to his disdain for history in favor of the science, of the philosophy and of the art, it formed, in part, the German cultural environment of the second half of the XIX century. Nietzsche, in this context, partially, in favor of the last one against the first ones, rebel against the teleological, optimistic idea of evolution progress of the reason spread out for the Aufklärung, but without falling in the schopenhauerian pessimism. Human history, according with our philosopher, instead of walking route to evolutionary progress for the best, finishes for walking in a disease and decay process.

At Nietzsche's time there was, already a proud historical culture of his scientific character developed. Raised to the scientific statute at that time, history intended to reach the positiveness through of the intelligibility of the facts, excluding from its fundament the contingencies that hinder the severity and the scientific objectivity. With The Use and Abuse of History (1874), that consists on one of the first and the most important written anti-historicism ones, Nietzsche send a corrosive critical on one to the historical culture, that, according to him, eliminated from the action the man, confining him in the past, hindering him from an authentic present as of a future hope. In the last instance, what is present in this writing, and had already it been present previously in the conferences Über die Zukunft unserer Bildungsanstalten Einleitung (1872) and in first Thoughts out of Season (1873) is one repudiate to the culture, especially the German, one based on an encyclopedic way and mere nostalgic education, that does not considerer the present action, enfeebling the life, hindering, in this way, the formation of high beings. However, in The Use and Abuse of History, the critical one is sent more specifically against the historicism:

- Unzeitgemäss ist auch diese Bertrachtung, weil ich etwas, worauf die Zeit mit Recht stolz ist, ihre historische Bildung, hier einmal als Schaden, Gebreste 
und Mangel der Zeit zu verstehen versuche, weil ich sogar glaube, dass wir Alle an einem verzehrenden historichen Fieber leiden und mindestens erkennen solten, dass wir daran leideen (Nietzsche, 1988: B. 1, p.246).

The interpretation of history as fault and defect (das Schaden, das Gebrechen, der Mangel) is the central point of this Thoughts out of Season, and, to recoup the health, Nietzsche advises to reduce the contact with the historical formation, what he is advantageous for the life. In this way, "life" starts to be the criterion that distinguishes health and disease state. In short, what it is in question in this writing is the value or not value of history for the life, that is, one is about an inquiry concerning the meaning of the historical sense, if it has value for the life or if it is a mere speech empty and unprovided of sense. In this The Use and Abuse of History, the critical one to history is applied, then, to evidence of the degeneration of the historical sense, to a hypertrophy of the contemplation of the past that finishes for weakening the vital program. Notwithstanding these damages of history for the life, its services are also necessary for it. History, according to Nietzsche, interests the men for three reasons: 1st, because they act and pursue an end; 2 nd, because they conserve and venerate what it was; 3rd, because they have freedom necessity. To these three reasons corresponds the three predominant forms of history: the antiquarian form, critical and the monumental one. The first one corresponds to a type of history, conservative and venerating of the past, that if finds stubborn for the origin. However, it attributes to too much value the insignificant things, compromising for excessively the life that starts to be essentially memory and commemoration. Second, critical history proceeds from contrary way; before everything, one confides for the present and it makes of it standard of the last things; it leads history to forum present, which means, judging and condemning the past and, with this, it intends to break the necessary chain that it comes of it to the present. Finally, the monumental history that searches in the past models for future action, that means, the exemplarities of that was and still it is great functions as impulse in the direction of the future. Monumental history corresponds to an attitude which according to if him projects for the future: either the look of who it believes the humanity due to largeness of the past and, therefore, it acts and it launches for the future his hope; either in the look of who abjure the present and, without hope in the future, nourishes his resignation and nostalgia in the great ones of the past.

In his three forms, the historical sense is effectively a necessity for the men, however only in the measure where this look for the past is not stimulated by forces and ends that do not create impediment for action in the present, nor raises obstacles to the construction of a future that is not mere repetition of the past. In this way, for Nietzsche when the life considers the greatest tasks, then the interest for audacious projects of the past shows. Only in the determined will of future, however, one also shows what there was of future in all passed. If the vital program, the project of life for the future sinks, the accumulation of know description becomes a pack, a danger for the life; the man learns, then, in history 
only the uselessness of all the projects; the empty life of creative impulses for the future is refuge in the past, look for to forget its own emptiness in the strange fullness the lived life.

The perception of the lack of historical sense in universal history, evidenced since The Use and Abuse of History, and also in some posthumous fragments of that time, 1874-1876, will be retaken, later, in the published works, in: Human, All-too-Human (HH) I, 2; HH, II, "Vermischte Meinungen und Sprüche" (MS), 17; GS, 337; Beyond Good and Evil (BGE), 224; Genealogy of Morals (GM), prologue and I, 2; Twilight of the Idols, (TI) "A Reason in the Philosophy", 1; Ecce Homo (EH), "The Season", 1; and also, in the posthumous one of 1888, commentary the HH I, 2 (Nietzsche, 1988: B. 14, p. 121). The position of Nietzsche in relation to this subject nor always was the same one, varying in accordance with the phases of the development of his philosophy.

In this way, in his first writing on the subject and in the posthumous ones of the time-as we saw above-the philosopher is sufficiently corrosive in his critical one to the historical direction, for leading the humanity to a writing of the history that he arrests to the past and the scientific objectivity, compromising and weakening all vital program. In the second phase of his intellectual production, marked deeply for his approach with sciences, Nietzsche sees the dynamic of the historical sense as a great conquest of science and the philosophy that he intends to establish, in opposition to old metaphysics. This can be illustrated with the following passage:

- Mangel an historichem Sinn ist der Erbfehler aller Philosophen (...). Alles aber ist geworden; es giebt keine ewigen Thatsachen: sowie es keine absoluten Wahrheiten giebt-Demnach ist das historiche Philosophiren von jetzt ab nothing und mit ihm die Tugend der Bescheidung (HHI, 2).

And yet, in $M S, 17$, when the happiness of the historian opposes to the philosopher's one, "...im Gegensatze zu den Metaphysikern-the historian-glücklich arüber ist, nicht 'Ein unsterbiche Seele', sondern viele stebliche Seelen in sich beherbergen". Taken for these two positions as to the historical sense, Nietzsche-yet in the second phase of his work-in GS, aphorism 337, speaks in double a meaning one of the concept,

- Wenn ich mit den Augen eines fernen Zetalters nach diesem hinsehe, so Weiss ich an dem gegenwärtigen Menschen nichts Merkwürdigeres zu finden, als seine eigenthümliche Tugend und Krankheit, genannt "historische Sinn".

To leave of this period, Nietzsche when dealing with the subject of the historical sense, will have a critical or festive position, depending on the context of insertion of the problematic one. Thus, in the TI, "The Reason in the Philosophy", 1 , we see the philosopher to make a compliment to historical sense and, in $B G E$, 224 and $E H$, "The Season", 1, one critical fort. In this period, also, according to our interpretative hypothesis, the idea of historical sense already appears associated to the subject of the nihilism. 
This is without doubt a peculiarity sufficiently detached and bold of our inquiry, to join the two subjects of the nietzschean reflection on history, being respected the chronology of appearance of each one of them. In the studies on the question of history, in Nietzsche, the two subjects are analyzed, thick way, separately for his interpret: or to be engaged to manage affair of historical sense, so as it can be evidenced in Kofman (1973), Schnädelbach (1991) ${ }^{1}$ and Gehardt $(1988)^{2}$; or to be engaged to manage affair of nihilism, so as it can be seen in Heidegger ${ }^{3}$, Michel Foucault (1967), Gilles Deleuze ${ }^{4}$ and Müller-Lauter ${ }^{5}$. However, there still are the ones that make worse, without respecting beginning of the concept of nihilism in the works of the author; consider the present subject since his first writings. Our interpretative hypothesis, provisory, is of that from the sprouting of the concept of nihilism in his works, Nietzsche extends his reflection on the history of the humanity, understanding as being a development's process of disease and decline, such as already it appeared initially in the above-mentioned texts of The Use and Abuse of History, and, later, in 1881, in aphorism 337 of $G S$, however, now, together with the problematic one of the nihilism, also appears a reflection on the possibility of the overcoming of this "pathological state", from a project of a "revaluation of all values".

\section{Nihilism}

We can see, thus, as the Nietzsche's critique of the historical culture, as responsible for the degeneration of the human life; it will be radicalized still more from 1881, with the elaboration of the nihilism concept that gains a prominence in his works, as more in the texts published in life as in the posthumous ones. For a purified understanding of concept, we will give to more emphasis to the dedicated passages it: in the edited works, GS, Thus Spoke Zarathustra (TSZ), BGE, GM, TI, The Antichrist (AC); in the posthumous ones, in the volumes, 9, 10, 11 and 13 of Kritische Studienausgabe (KSA).

The concept of nihilism ${ }^{6}$ is not originality nietzschean; already it was current as European philosophy as literature of XIX century, it appeared as a time symptom, in the work of diverse thinkers; for example, in William Hamilton, Jacob, Jean-Paul, Dostoyevsky, Turguenieff, in the romantic poets German, the russian anarchists, the schopenhauerian pessimism and Paul Bourget, of who our philosopher adopted the expression. With the term nihilism, Nietzsche it wanted to assign, on the other hand, the threatening crisis in which is launched the modern world, the depreciation of the universal values that launches the humanity in the overwhelming situation of that nothing more it has felt; on the other hand, it is applied as his internal logic, when uncurling of all European

\footnotetext{
${ }^{1}$ Schnädelbach (1991). Filosofía en Alemania (1831-1933). Trad. Espanhola. Madrid: Ediciones Cátedras. See Chapt. 2.

${ }^{2}$ See page. 133-162.

${ }^{3}$ Heidegger (1961). II, Chaps V bis IX. See too, Heidegger (1950: pp. 193-194).

${ }^{4}$ Deleuze (1962). See Chaps. II, IV e V.

${ }^{5}$ Müller-Lauter (1971), pp. 34-65.

${ }^{6}$ For a more detailed study of the concept of nihilism in Nietzsche, see KUHN $(1984,1989,1992)$.
} 
history called, since Plato, accenting itself with the Christian moral. In the measure where it has lead the process of historical development of the humanity, the nihilism always made present as his internal logic, before and after his confirmation, as the philosopher says: Was ich erzähle, ist die Geschichte der nächsten zwei Jahrhunderte. Ich beschreibe, was kommt, was nicht mehr anders kommen kann: die Heraufkunft des Nihilismus (Nietzsche, 1988: B. 8, p.411). Despite the predictive tone of Nietzsche, of that if it is speaking in this posthumous one, it is of the modern history, over all European, that it disclosed a shady future, due to perception of the fall of the values that supported the culture until then. In continuity with what it was said, sentences:

- Diese Geschichte kann jetzt schon erzählt werden: denn Nothwendigkeit selbst ist hier am Werke. Diese Zukunft redet schon in hundert Zeichen, diese Schicksal kündigt überall sich an; für diese Musik der Zukunft sind alle Ohren bereits gespitzt. Usere ganze europäische Cultur bewegt sich seit langem schon mit einer Tortur der Spannung, die von Jahrzehnt zu Jahrzehnt wächst, wie auf eine Katastrophe los: unruhig, gewaltsam, überstürzt: wie ein Sturm, der ans Ende will, der sich nicht mehr besinnt, der Furcht davor hat, sich zu besinnen (Idem).

This form, coinciding with the history of the same humanity, the nihilism can be called with justice of his normal condition. He constitutes, however, also, and, over all, while disease of the man contemporary, a psychological and transitory state. The culture and, therefore, the man, are taken nihilism, as much as experience and feeling of a current critical state, how much as critical thought that the man and the culture make against the beliefs, the values and ideals of the great tradition. Therefore, in the sketch of composition of the controvertible works, Will to Power (WP), the philosopher says: Der Nihilimus steht vor Thür: woher kommt uns dieser unheimlichste aller Gäste? (Nietzche, 1988: B. 11, p.127). Before every thing, it installs maliciously as gloomy feeling; later, as frightening feeling of the failure of all senses. It is the gradual exhaustion of all the directions, the kingdom in expansion of the emptying of the directions. It is the moment that it tries as it was a nightmare or complete disorientation, Die Wüste wächst (Nietzsche, 1988: B. 4, p. 380). All the values that directed the sense had depleted, they had occulted, they had denied, lack the goals. The nihilism as the experience of the exhaustion of the senses, translates a great fatigue, the great tired of the man by itself. It is an infinite agony, an interminable twilight. This moment is express for Nietzsche with the phrase "God is dead" (Gott ist tot). Such sentence does not have only the meaning of a critical one to the religion and nor summarizes to the atheistic movement en vogue in XIX century. The critical one that it suggests is much more general and encloses all thought with pretensions to build universal values, such as: last unit, truths and purpose. The God, who died, was who guarantee the order: metaphysics, epistemological and moral of the world. With his death, the set of the ideals and the values that directed the historical sense is denounced as unprovided of felt and becomes products of an illusion. The moment of the taking of conscience of the death of 
God, for Nietzsche, is most dangerous of all, therefore it points with respect to two ways: one-that he would like that the humanity followed-is the way of the revaluation, the conscience taking, one we are command, that means, there aren't external authority that in it guides them, but we are ourselves who we lead history; the other is the danger that this perception can launch on the humanity, therefore such taking of conscience discloses that to that where we deposited highest hope is unprovided of value, is fiction and it discloses, thus, as the nothing. This feeling of nothing restored by the absence of God can launch the most calamitous and misty humanity in of the times, in which nothing valley the penalty, everything is in vain (das Umsonst).

Provided that is a complete disorientation, the nihilism can radically invert his illusory felt in a lack of sense. One is about a will that, ahead of the verification of that nothing it has sense, satisfies with this lack and, already resigned of this, affirms this nothing empty as being the sense, bringing great consequences to the life and the humanity as a whole; therefore, Nietzsche says: "Eine Interpretation gieng Grunde, weil sie aber als die Interpretation galt, erscheint es, als ob es gar keinen sinn im Dasein gebe, als ob alles umsonst sei." (Nietzsche, 1988: B. 12, p. 212). The terrible message of the death of God, in last instance, is that the nothing (das Nichts) and the in vain constitutes the truth of the superior values. The position of acceptance of the nothing can well be illustrated in the figure "Der Wahrsager", personage of books TSZ, that represents the prophet of the nihilism-the caricature of Schopenhauer-which fold that "Alles ist leer, AIllesist gleich, Alles war!" (Nietzsche, 1988: B. 4, p. 172).

However, this is not the final position of Nietzsche that would not be differentiated of the one of his old master. The conception of nihilism the one that he adheres frequently is called active nihilism, which is not moved by a pessimism, but, before, for an optimism of the life, express in the affirmative thought of the eternal return, “...diese höchst Formel der Bejahung, die überhaupt erreicht warden kann" (Nietzsche, 1988: B. 6, p. 335). The nihilism while historical process is necessary and its necessity implies necessarily in his overcoming. Thus, it does not meet surpassed simply because the metaphysical distinctions invented by Plato leave to be valid. But, for a transformation of the nihilism most radical, that means, to pass of the dissolutions reactive and passive for an active dissolution, he has of if including in the destruction of all the metaphysical and moral bonds that until then had built the culture, an act of affirmation of the life. And is in this last sense, as cancellation of all the metaphysical dichotomies and as radical suppression of the world truth, that the nihilism could be thought as set free of the paralysis of the only and annunciating of a "revaluation of all values".

\section{Conclusion}

Nietzsche's conception of history has, this form, certain peculiarity, that is basic in relation to the traditional Philosophy of History, therefore this, as in a French version, with the Positivism of Comte or with Romanism of Condorcet, as about 
a German version, either to la Kant or la Hegel, thinks the history of the point of view of a performatic progress; Nietzsche, about diametrical opposing position to these points of view, thinks history as a nihilism or decay development. As much the decay how much the nihilism is symptoms of the malaise restored in the humanity, due to lack of historical direction. And, for being also a reflection concerning the origins of this suffering (décadence and nihilism), later, in the Genealogy of Morals (1886), after, Nietzsche will call his "historical method" of interpretation of the culture, genealogical.

\section{References}

Deleuze, G. (1962). Nietzsche et la philosophie. Paris: PUF.

Foucault, M. (1967). Nietzsche, Freud, Marx. In Nietzsche. Cahiers de Royaumond. Paris: Les Édition de Minuit.

Gehardt, V. (1988). Pathos und Distanz. Verl: Reclam Stuttgart.

Heidegger, M. (1950). Nietzsches Wort “Gott ist tot”. In Holzwege. Frankfurt: Klostermann.

Heidegger, M. (1961). Nietzsche. 2 B., Pfulliger, Neske.

Kofman, S. (1973). Le/Les "concepts" de Culture dans les Intempestives ou la double dissimulation. In Nietzsche Aujourd'hui? Tome II., Paris : Union Générale d' Édition.

Kuhn, E. (1984). Nietzsches Quelle des Nihilismus-Begriffs. In: Nietzsche-Studien 13. Berlim: Walter de Gruyter. https://doi.org/10.1515/9783110244328.253

Kuhn, E. (1989). Cultur, Civilization. Die Zweideutigkeit des "Modernen". In Nietzsche-Studien, N. 18. Berlin/New York: Walter de Gruyter.

Kuhn, E. (1992). Friedrich Nietzsches Philosophie des europäischen Nihilismus. Berlin/New York: Walter de Gruyter. https://doi.org/10.1515/9783110875348

Müller-Lauter, W. (1971). Nietzsche, Seine Philosophie der Gegensätze und die Gegensätze seiner Philosophie. Berlim/Nova York, Walter de Gruyter. https://doi.org/10.1515/9783110829471

Nietzsche, F. (1988). Kritische Studienausgabe. In: 14 B.-Herausgegeben von G. Colli, \& M. Montinari. Berlin/NY: dtv/de Gruyter.

Schnädelbach, H. (1991). Filosofía en Alemania (1831-1933). Trad. Espanhola. Madrid: Ediciones Cátedras. 